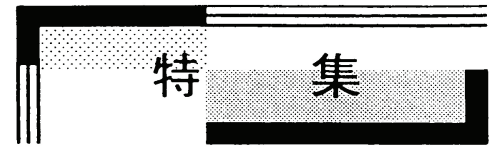

\title{
複雑流体の粒子分散系としての表現と流動誘起構造シミュレーション*
}

\section{Expression of Complex Fluids as Particle Dispersion Systems and Numerical Simulation of

\author{
Their Flow-Induced Structures
}

\author{
山本 剛 宏** \\ YAMAMOTO Takehiro
}

\begin{abstract}
The numerical analysis of flow-induced structures of complex fluids is one of effective approaches for elucidating the mechanism of their complicated flow behavior. In this article, three examples of the numerical simulation of the flow-induced structure using the Brownian dynamics (BD) method and the multi-particle collision dynamics (MPCD) method are presented: (a) BD simulation of shear flows of polymer/clay suspensions, (b) MPCD simulation of shear flows of linear polymer solutions, and (c) MPCD simulation of bio-convection of phototactic microalgae in water. In these simulations, complex fluids are modeled by dispersion systems of basic elements of the fluid inner structure such as particles and model polymers, and their behavior is analyzed for the investigation of the flow-induced structure.
\end{abstract}

Keywords: Complex fluids, Flow-induced structures, Brownian dynamics, Multi-particle collision dynamics

\section{1. 緒 言}

流体内部に原子・分子サイズよりも大きなサイ ズの構造をもつ流体を複雑流体 (complex fluids) と呼び、例えば、高分子流体、液晶、サスペンシ ヨン、エマルションなどがその代表例である。一 方、流体力学の分野ではニュートン流体と非ニュ ートン流体という分類がされてきた。ニュートン 流体では応力がひずみ速度に比例し、その比例係 数が粘性係数 (粘度) である。このような比例関 係が成り立たない流体を非ニュートン流体と呼 び、粘度はひずみ速度に依存する。多くの複雑流 体は非ニュートン流体となるが、流体の内部構造 を意識する際には、複雑流体という呼び方が用い られることが多い。

1991 年にノーベル物理学賞を受賞した de Gennes は受賞講演 [1] でソフトマター（soft matter）について講演を行なった。その中でソフ トマターは複雑流体とも呼ばれていると紹介し、
それぞれの表現は、両者がもつ二つの特徴を代表 していると述べている。すなわち、ソフトマター は柔軟性（flexibility）を、複雑流体は複雑性 （complexity）を代表しているという。複雑流体 は、その複雑な流体内部構造に特徴があり、複雑 流体の特異な流動挙動は、流動によって発生する 内部構造の変化 (流動誘起構造) に起因する。し たがって、複雑流体の流動現象のメカニズムの本 質的な理解は、流動誘起構造の解明にあると言え る。そこで、実験では、流動複屈折や二色性など 流動誘起構造に関連するデータの計測が進めら れ、数值解析では、流体のレオロジ一特性に基づ いて現象の解析を行う従来の手法に加えて、流動 誘起構造の解析を基盤にした研究が進められる ようになってきた。

ここでは、複雑流体を流体内部構造の基本とな る要素（粒子やモデル高分子など）の分散系とし て表現し、流動誘起構造の数值シミュレーション

* 2020.1.10 受付

** 大阪電気通信大学工学部機械工学科 † 572-8530 大阪府寝屋川市初町 18-8

TEL: (072)812-3392 FAX: (072)812-3392 E-mail: tyamamot@osakac.ac.jp 
を行う方法について概説する。本稿では、ブラウ ン動力学 (Brownian Dynamics, BD) シミュレーシ ヨンおよび Multi-Particle Collision Dynamics (MPCD) シミュレーションを用いた解析例を紹 介する。

\section{2. 流体内部構造シミュレーション手法}

\section{1 ブラウン動カ学シミュレーション}

複雑流体の内部構造のシミュレーションでし ばしば使用される粗視化分子動力学法では、粒子 と溶媒分子の間の衝突を扱う必要があるため、ブ ラウン運動の影響を考慮することが容易ではな い。 BD シミュレーションでは、ブラウン運動を 乱数を用いたランダム力を用いて表現すること により、その効果を考慮したシミュレーションを 現実的な計算負荷で実現する $[2,3]$ 。

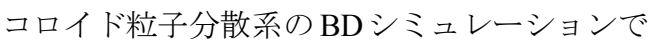
は、粒子の並進運動と回転運動の方程式を解く。 一般に粒子近傍では速度勾配が一様であると仮 定される $[2,3]$ 。運動方程式はそれぞれ粒子には たらくカおよびトルクの釣り合いの式で記述さ れる。

$$
\begin{aligned}
& \boldsymbol{F}_{i}^{\mathrm{P}}-\boldsymbol{F}_{i}^{\mathrm{V}}+\boldsymbol{F}_{i}^{\mathrm{B}}=\mathbf{0} \\
& \boldsymbol{T}_{i}^{\mathrm{P}}-\boldsymbol{T}_{i}^{\mathrm{V}}+\boldsymbol{T}_{i}^{\mathrm{B}}=\mathbf{0}
\end{aligned}
$$

ここで、 $\boldsymbol{F}_{i}, \boldsymbol{T}_{i}$ は粒子 $i$ にはたらくカとトルクで上 付き添字 $\mathrm{P}, \mathrm{V}, \mathrm{B}$ はそれぞれ粒子間相互作用、粘性 抵抗、ブラウン力に起因する量であることを示す。 式の詳細については文献 [2-6]などを参照された い。非球形粒子の場合には、溶媒との粘性摩擦や ブラウン力を表すランダム力は粒子形状の異方 性を考慮したものとなる [2, 4-6]。また、希薄系 の場合には粒子間の相互作用は考慮しないが、そ うでない場合にはその考慮が必要となり、一般に は、ポテンシャル関数を用いて粒子間相互作用を 記述する。

\subsection{Multi-Particle Collision Dynamics シミュレー ション}

溶媒を介した粒子間相互作用（流体力学的相互 作用、Hydrodynamic Interaction）は流体内部構造 変化に影響を及ぼす因子であるが、この効果を BD シミュレーションで導入するためには、HI ンソルを用いるなど、計算量が大幅に増加する計 算が必要となる $[2]$ 。流体力学的相互作用を比較

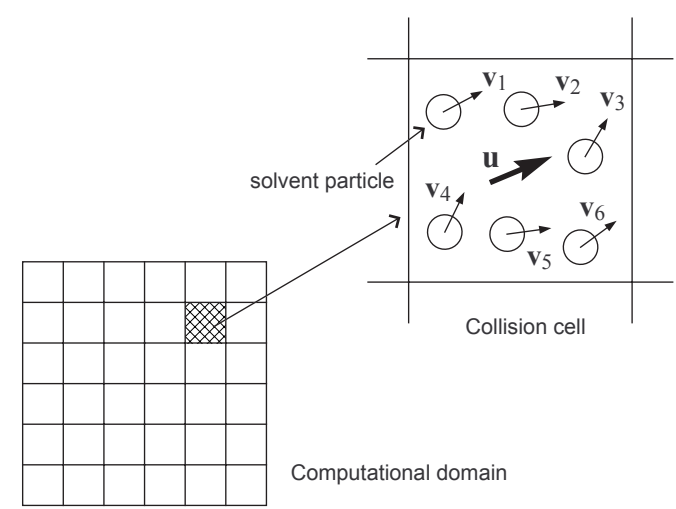

Fig. 1 Schematic diagram of collision cell.

的計算量を抑えて導入できる数值シミュレーシ ヨン手法の一つが MPCD である。

MPCD では流体を仮想質点粒子 (溶媒粒子) の 集合としてモデル化し、粒子間の衝突を計算する 衝突ステップ (collision step) と粒子の移動を計 算する移動ステップ (streaming step) の 2 ステッ プからなる [7]。MPCD では、粒子間の衝突を衝 突セル (collision cell) 内の粒子間の運動量交換と して表現する（Fig. 1）。衝突による運動量交換を 通じて流体の粘性の効果が表される。運動量交換 には種々の方法が提案されている。代表的なもの に、SRD (Stochastic Rotation Dynamics) や MPC-AT (MPCD with Anderson Thermostat) などがある [7]。移動ステップでは、衝突ステップで更新され た各粒子の速度にしたがって粒子の移動が行わ れる。

$\mathrm{SRD}$ では衝突ステップにおいて粒子速度 $\boldsymbol{v}_{i}$ は 次式のように更新される.

$$
v_{i}^{n+1}=u^{n}+R\left(v_{i}^{n}-u^{n}\right)
$$

ここで、 $\boldsymbol{u}$ は衝突セル内の質量中心の速度べクト ル、R はランダムな方向への一定角度の回転行列 である。ただし、同一セル内においては各粒子の 回転の方向は同じにする。上付き添字 $n$ は計算 ステップを表す。SRD は比較的計算負荷が低いが、 系の運動量は保存されるが角運動量は保存され ない点に注意が必要である。

運動量と角運動量がともに保存される計算手 法に MPC-AT+a がある。MPC-AT+a スキームでは、 衝突ステップ後の粒子 $i$ の速度は式(4)で表される 
相対速度 $\delta \boldsymbol{v}_{i}$ を衝突セル内の質量中心の速度べク トルに加えることで求められる。

$$
\begin{gathered}
\delta \boldsymbol{v}_{i}=\boldsymbol{v}_{i}^{\mathrm{ran}}-\frac{\sum_{j \in \mathrm{cell}} m_{j} \boldsymbol{v}_{i}^{\mathrm{ran}}}{\sum_{j \in \mathrm{cell}} m_{j}} \\
-\boldsymbol{\Pi}^{-1} \sum_{j \in \mathrm{cell}}\left[\boldsymbol{r}_{j \mathrm{c}} \times m_{j}\left(\boldsymbol{v}_{j}^{\mathrm{ran}}-\boldsymbol{v}_{j}^{\text {before }}\right)\right] \times \boldsymbol{r}_{i \mathrm{c}} \\
\boldsymbol{r}_{i \mathrm{c}}=\boldsymbol{r}_{i}-\boldsymbol{R}_{\mathrm{c}}
\end{gathered}
$$

ここで、下付き添え字 $i$ は粒子 $i$ の值であること を表す。 $\boldsymbol{v}_{i}^{\mathrm{ran}}$ は Maxwell-Boltzmann 分布から得ら れたランダム速度、 $v_{i}^{\text {before }}$ は前ステップの速度ベ クトル、 $m_{i}$ は粒子質量、 $\boldsymbol{r}_{i}$ は位置ベクトル、 $\boldsymbol{R}_{\mathrm{C}}$ は衝突セルの質量中心の位置ベクトル、クは慣性 モーメントテンソルである。また、総和記号は衝 突セル内の全粒子に関する総和を取ることを意 味する。式(4)の右辺第 3 項は角運動量を保存する ために MPC-AT の計算式に追加された項である。

次章では、これらの計算手法を用いた複雑流体 の数值解析例を紹介寸る。

\section{1 ポリマー・クレイ粒子分散系のブラウン動カ}

学シミュレーション

\subsection{1 回転楕円体モデル}

BD シミュレーションの例として、ポリマー・ クレイ粒子分散系のせん断流れ下の流動誘起構 造シミュレーションを紹介する。ここでは、クレ イ粒子を扁平回転楕円体でモデル化し、高分子を 弾性ダンベルモデルで表した $[5,6]$ 。

クレイ粒子は円板状粒子で近似できるが、円板 間の相互作用を表すポテンシャル関数を設定す ることは難しい。そこで、回転楕円体粒子で円板 を近似する。細長回転楕円体では液晶のような棒 状分子を近似でき、扁平回転楕円体では円板状粒 子を近似できる (Fig. 2)。

回転楕円体粒子間の相互作用は、Gay-Berne (G-B) ポテンシャル [8] を用いて表される。Fig. 3 に示すように GB ポテンシャルは粒子の配置に よって関数形状が異なり、粒子形状の異方性の効 果を表現できる。

\section{1 .2 弾性ダンベルモデル}

線形高分子をモデル化する方法に弾性ダンベ ルモデルがある（Fig. 4）。弾性ダンベルモデルは 2 個のビーズをバネで連結したもので、高分子が 示す粘弾性をバネの弾性とビーズの粘性抵抗で 表現する。バネに有限伸長性の非線形バネ
(Finitely Extensible Nonlinear Elastic spring, FENE spring）を用いたモデルを FENE ダンベルモデル $[9,10]$ と呼ぶ。

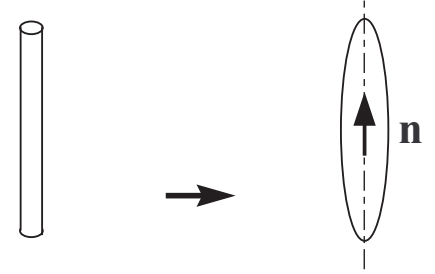

rod-like particle prolate spheroid

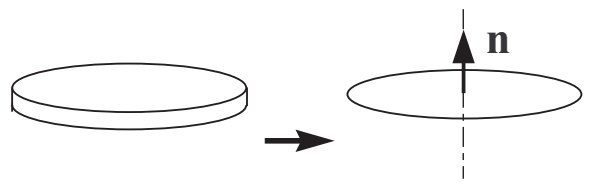

\section{disc-like particle oblate spheroid}

Fig. 2 Schematic diagram of spheroidal model. Unit vectors $\boldsymbol{n}$ in the rotation-axis direction indicate the particle direction.

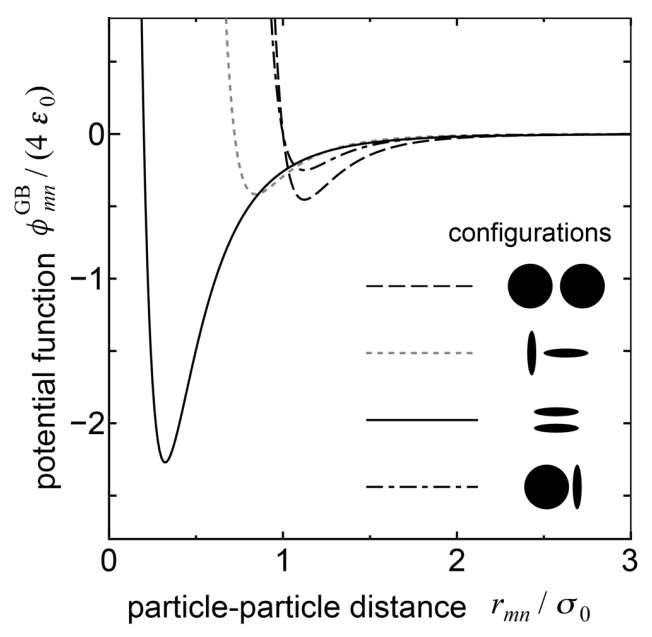

Fig. 3 Gay-Berne potential. Illustrations in the figure indicate four typical configurations of two disc-like particles. The potential function depends on the configuration. 


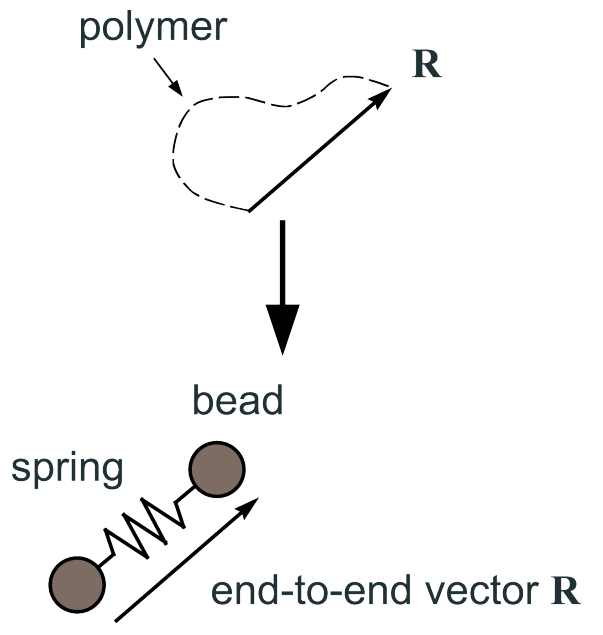

\section{elastic dumbbell}

Fig. 4 Schematic diagram of elastic dumbbell model.

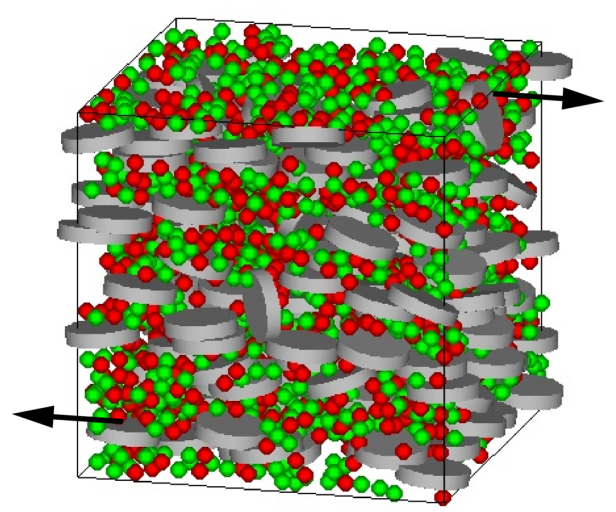

Fig. 5 Snapshot of shear flow of FENE dumbbells and oblate spheroid particles suspension. Arrows indicate the direction of shear.

回転棈円体粒子間の相互作用には GB ポテンシ ヤルを、FENE ダンベルのビーズと回転楕円体粒 子との相互作用には修正 GB ポテンシャルを適用 する [11]。ビーズ間の相互作用には斥力のみを考 慮した Repulsive Lennard-Jones（RLJ）ポテンシャ ル $[5,6]$ を適用した。

\section{1 .3 せん断流れ}

せん断流れの数值シミュレーションを行うた めに、Lees-Edwards $の$ 周期境界条件 [3,12]を用い

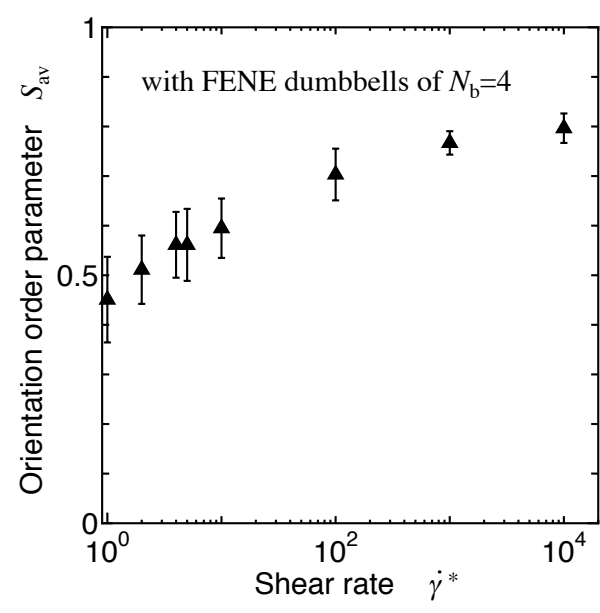

(a)

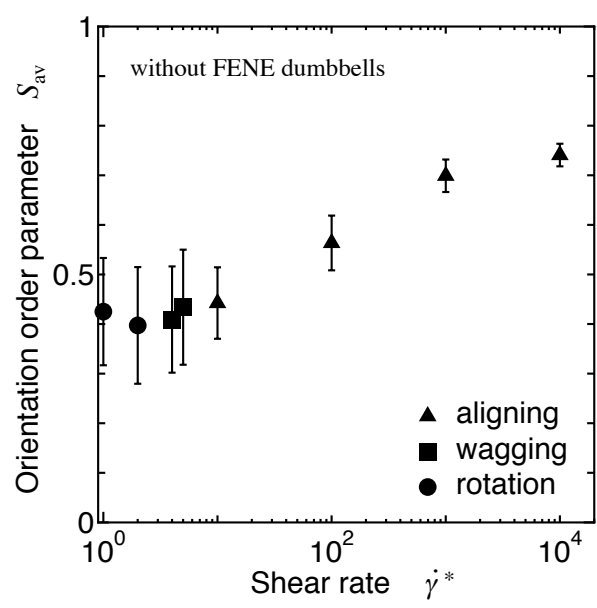

(b)

Fig. 6 Time average scalar order parameter $S_{\text {av }}$ as a function of shear rate for suspensions of disc-like particles with (a) and without (b) FENE dumbbells.

た。Lees-Edwards の周期境界条件では、せん断流 れによる粒子の移動量にしたがって計算セルに 出入りする粒子の位置をずらすことでせん断流 れを表現する。

Fig. 5 にシミュレーション結果のスナップショ ットを示寸。円板状の粒子がクレイ粒子のモデル で、球はダンベルモデルのビーズを示している。 円板表面をせん断面に平行に近い向きにした配 向をしている粒子が多く存在することがわかる。

Fig. 6 に高分子が存在する場合としない場合の 
model polymer solvent particle

\begin{tabular}{|c|c|c|c|}
\hline $\mid \begin{array}{llll}0 & 0 & \\
& 0 & 0 \\
0 & 0 & & \\
& 0 & 0 & \\
0 & 0 & 0\end{array}$ & $0_{0}^{0}$ & 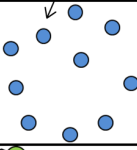 & $\begin{array}{cccc} & 0 & 0 \\
0 & & 0 \\
0 & 0 & 0 & 0 \\
0 & 0 & 0 \\
0\end{array}$ \\
\hline $\begin{array}{cccc}0 & 0 & \\
0 & 0 & 0 \\
0 & 0 & 0 & \\
0 & 0 & 0 \\
0 & 0 & 0\end{array}$ & $0^{0} 0$ & & $\begin{array}{cccc}0 & 0 & 0 & 0 \\
0 & 0 & 0 & 0 \\
0 & 0 & 0 & 0 \\
0 & 0 & 0 & 0 \\
0 & 0 & 0 & 0\end{array}$ \\
\hline 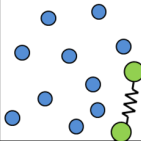 & $0_{0}^{0} \xi_{0}^{0}$ & $\begin{array}{llll} & 0 & 0 \\
0 & 0 & 0 \\
0 & 0 & 0\end{array}$ & $\begin{array}{ccc}0 & 0 & 0 \\
0 & 0 & 0 \\
0 & 0 & 0 \\
0 & 0 & 0\end{array}$ \\
\hline $\int_{0}^{0} \int_{0}^{1} \int_{0}^{0}$ & 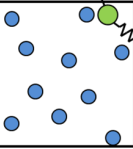 & $0_{0}^{0} 0_{0}^{0} 0$ & 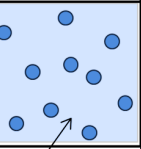 \\
\hline
\end{tabular}

collision cell

Fig. 7 Schematic diagram of model of polymer solution for MPCD.

粒子の平均配向度 $S_{\mathrm{av}}$ のせん断速度依存性を示す [5]。配向度はランダム状態で 0 、完全配向状態で 1 の值をとる。高分子が存在しない場合は、ダイ レクター (平均配向方向を表す単位ベクトル) が 回転するタンブリング現象やワギング現象が現 れる。しかし、線形高分子は流れ方向に配向する 傾向を示すため、高分子が存在することによって ダイレクターの回転は制限され、その結果全体的 に配向度が大きくなっている [5]。

\section{2 線形高分子分散系の MPCD シミュレーショ}

\subsection{1 高分子溶液のモデル}

Fig. 7 に示すように FENE ダンベルと溶媒粒子 の分散系として高分子溶液を表現する $[13,14]$ 。 ダンベルのビーズ間の相互作用には斥力のみを 考慮した RLJ ポテンシャルを適用した。ダンベル のビーズと溶媒粒子の間の運動量交換には MPC-AT+a スキームを用いた。

\subsection{2 せん断流れ}

せん断流れの数值シミュレーションを行うた めに、Lees-Edwards の周期境界条件 [12] を適用 した。

Fig. 8 に計算例 [14] を示す。これはワイセン ベルグ数 Wi が 0.077 と 7.7 の場合のスナップシ ヨットである。Wi は流れの弾性力と粘性力の比 を表す無次元数で、Wi が大きいほど弾性の効果

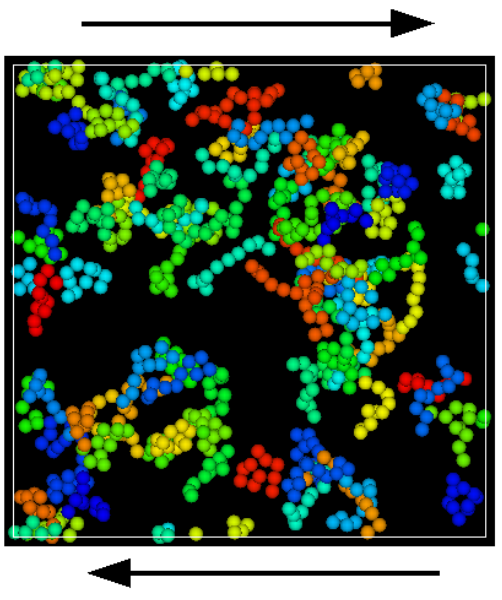

(a)

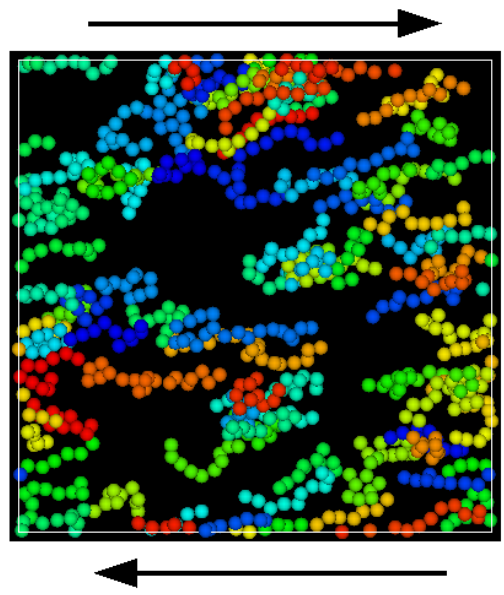

(b)

Fig. 8 Snapshots of shear flows of polymer solutions at $W i=0.077$ (a) and 7.7 (b). Arrows indicate the direction of shear.

が強いことを意味する。同じ流体であれば、せん 断速度が大きいほど Wi は大きい。Fig. 8 では分 子形状を見やすくするために、1728 個のモデル 高分子のうち、96 個のみを可視化している。図 より Wi が小さい場合は、モデル高分子は折り畳 まれた構造をしているが、Wi が大きくなると流 れ方向に伸長されている様子がわかる。Fig. 9 の モデル高分子の平均両端間距離 $\left\langle R>/ R_{0}\right.$ 分布の $W i$ 依存性の結果を見ると、Wi の増加とともに $<R>/ R_{0}$ が大きいモデル高分子の存在割合が増加 し、モデル高分子が伸長されていくことがわかる。 


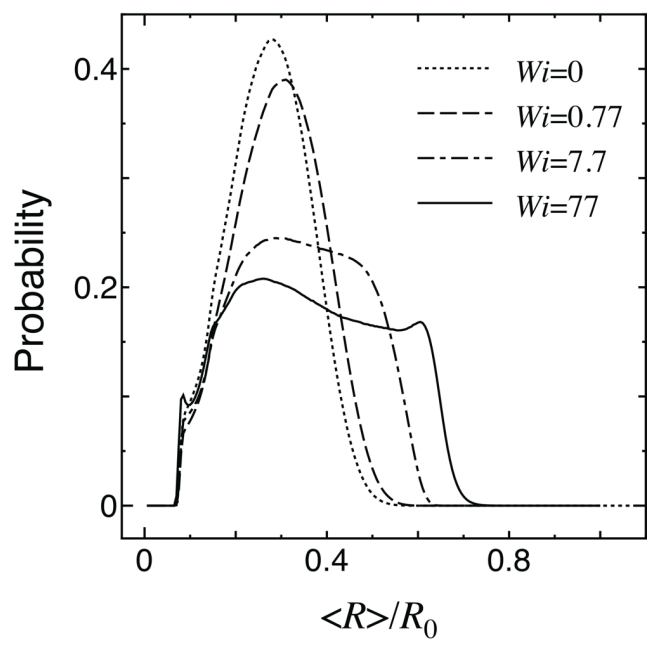

Fig. 9 Dependence of the average end-to-end vector $<R>R_{0}$ of the model polymers on the Weissenberg number $W i$.

流動誘起構造の数值シミュレーションでは、こ のような構造に関する解析だけではなく、構造に 関するデータから応力テンソルを評価し、せん断 粘度や法線応力差などの系のレオロジー特性を 評価することができる [15]。

\section{3 生物系粒子分散系への展開}

\subsection{1 生物系粒子分散系と複雑流体}

生物の集団運動 [16] やアクティブマターの運 動 [17] において、様々な構造が形成されること が知られている。それらの中には、複雑流体の内 部構造で見られるものと類似した構造が見られ る。微生物の分散系が通常のコロイド粒子分散系 と大きく異なるのは、コロイド粒子は流体からの 力や粒子間の相互作用によって運動する受動粒 子であるのに対して、微生物は自ら運動すること ができる能動粒子である点である。微生物を運動 能を有する能動粒子 (生物系粒子) の分散系とし て捉え、複雑流体の数值シミュレーション手法を 適用した解析モデルを紹介する。

光度によって運動を変化させる走光性を有す る微細藻類が水に分散している系を考える。微細 藻類は光合成に適した光量の位置に移動する特 性をもつ。ここでは、走光性微細藻類を、光量に よって移動速度を変える能動粒子 (微細藻類粒子

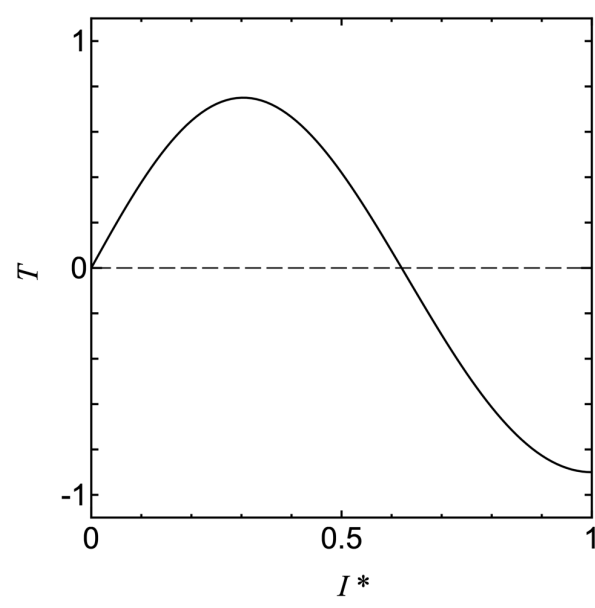

Fig. 10 Phototactic function $T\left(I^{*}\right)$ at $\beta=-0.1$.

と呼ぶことにする）として表現し、MPCD シミュ レーション手法の一つである SRD を適用する。

\subsection{2 微細藻類粒子モデル}

流路中の微細藻類分散系に外部から入射した 光の一部は微細藻類により吸収され、流路内で光 量は減衰する。ここでは、Lambert-Beer 則により 流路内の光量を計算する [18-20]。

微細藻類粒子の速度べクトル $v_{\text {photo }}$ は次式で与 えられる [18-20]。

$$
v_{\text {photo }}=w_{\mathrm{c}} T\left(I^{*}\right) \hat{\boldsymbol{z}}
$$

ここで、 $w_{\mathrm{c}}$ は微細藻類の最大速さ、 $\hat{z}$ は光源方向 の単位ベクトルである。 $I^{*}$ は式(7)の走光性関数 $T\left(I^{*}\right)$ が最小值となるときの值が 1 となるように正 規化した光量である。

$$
\begin{aligned}
& T\left(I^{*}\right)=0.8 \sin \left[\frac{3}{2} \pi \chi\left(I^{*}\right)\right]-\sin \left[\frac{1}{2} \pi \chi\left(I^{*}\right)\right] \\
& \chi\left(I^{*}\right)=I^{*} \exp \left[\beta\left(I^{*}-1\right)\right]
\end{aligned}
$$

ここで、 $\beta$ は定数である。Fig.10に $\beta=-0.1$ のと きの走光性関数を示す。 $T\left(I^{*}\right)=0$ となる $I^{*}(>0)$ が 最も光合成に適した光量となることを意味する。

\subsubsection{SRD とのカップリング}

細藻類粒子を仮想流体粒子と同様に扱い、衝突 ステップで微細藻類粒子も含めて SRD により運 動量交換を行い、微細藻類粒子と溶媒粒子の運動 
の計算をカップリングする [21]。そして、衝突ス テップにおいて、微細藻類粒子の速度更新の際に は、通常のSRDによる更新の他に式(6)で計算さ れる $\boldsymbol{v}_{\text {photo }}$ を加える。次に移動ステップで、微細 藻類粒子と溶媒粒子それぞれの位置更新を行う。

\subsection{4 生物対流}

Fig.11 に示寸直方体セル内の生物対流の数值 シミュレーンを行なった。溶媒粒子の初期位置は セル内にランダム配置し、初期速度は分散が $k_{\mathrm{B}} T$ / $m_{\mathrm{s}}$ となるような Maxwell-Boltzmann 分布から各 粒子の速度を与える。ここで $k_{\mathrm{B}}$ はボルツマン定 数、 $T$ は絶対温度、 $m_{\mathrm{s}}$ は溶媒粒子の質量である。 藻類粒子の初期位置もランダム配置とするが、初 期速度ベクトルは 0 とする。また、光は照射され ていないものとする。

境界条件として、各粒子に bounce-back 条件 [7] を適用することで、壁面にすべりなし条件を与え る。時刻 $t=0$ で一定光度の光を上方から照射する。 その他の壁面からの光の入射はないものとする。

Fig.12 にシミュレーション結果の一例を示す。 ここでは、速度ベクトルを示している。これより 微細藻類の走光性による運動に伴い溶媒の対流 が発生していることが分かる。この結果より、本 モデルを用いて生物対流の再現が可能であるこ とが示された。しかし、各パラメータの設定につ いては、実際の微細藻類との整合性などさらに検 討課題が残されている。

\section{4. 結 言}

本稿では BD シミュレーションおよび MPCD シミュレーションによる複雑流体の流動誘起構 造の数值解析例を紹介した。流体力学的相互作用 を比較的低負荷の計算でシミュレーションに導 入することができる MPCD の応用は今後の発展 が期待される分野である。また、本稿では紹介し なかったが、流体内部構造シミュレーションとマ クロ流動解析とのカップリングも重要な研究課 題である。

\section{参考文献}

[1] de Gennes, P. G., Soft Matter, Rev. Mod. Phys., Vol. 64(3), 645-648 (1992).

[2] Kamiyama, S. and Sato, A., Microsimulation of Colloidal Dispersions, Asakura Shoten, Tokyo (1997).

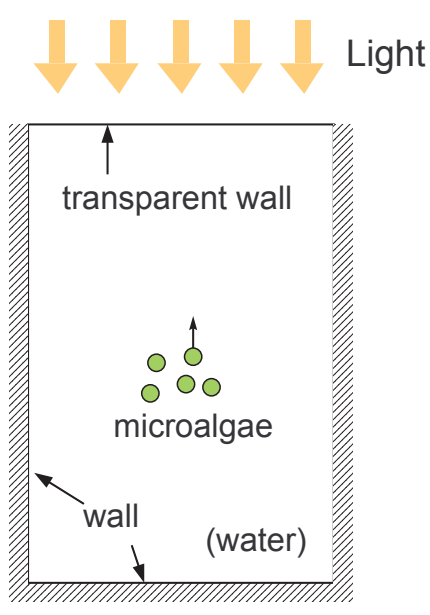

Fig. 11 Schematic diagram of flow cell and boundary conditions.

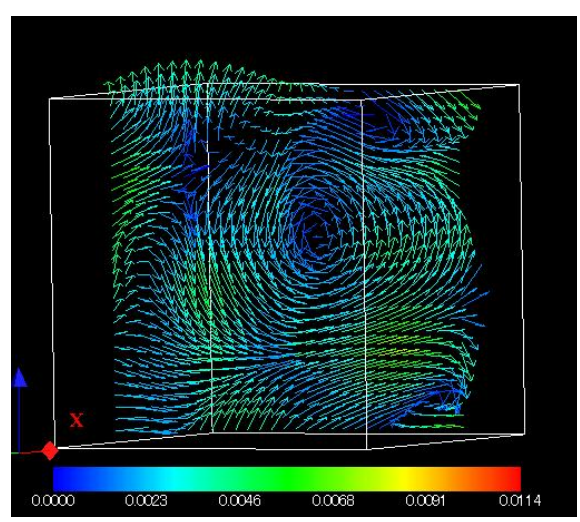

Fig. 12 Example of numerical results of simulation of bio-convection in a cubic cell (velocity vectors).

[3] Allen, M. P. and Tildesley, D. J., Computer Simulation of Liquids 2nd Ed., Oxford Univ. Press, Oxford (2017).

[4] Yamamoto, T., Brownian Dynamics Simulation for Spheroid Particle Suspensions in Polymer Solution, Rheology of Non-Spherical Particle Suspensions (Ed. Chinesta, F. and Ausias, G.), ISTE-Elsevier, London (2015).

[5] Yamamoto, T. and Kasama, H., Brownian Dynamics Simulation of Multiphase Suspension of Disc-Like Particles and Polymers, Rheol. 
Acta, Vol. 49(6), 573-584 (2010) (doi:10.1007/ s00397-009-0405-5).

[6] Yamamoto, T. and Kanda, N., Computational Model for Brownian Dynamics Simulation of Polymer/Clay Nanocomposites under Flow, J. Non-Newtonian Fluid Mech., Vols.181-182, 1-10 (2012) (doi:10.1016/j.jnnfm.2012.06.005).

[7] Gompper, G., Ihle, T., Kroll, D. M. and Winkler, R. G., Multi-Particle Collision Dynamics: A Particle-Based Mesoscale Simulation Approach to the Hydrodynamics of Complex Fluids, Adv. Polym. Sci., Vol. 221, 1-87 (2009) (doi:10.1007/12 2008 5).

[8] Gay, J. G. and Berne, B. J., Modification of the Overlap Potential to Mimic a Linear Site-Site Potential, J. Chem. Phys., Vol. 74(6), 3316-3319 (1981) (doi:10.1063/1.441483).

[9] Bird, R. B., Curtiss, C. F., Armstrong, R. C. and Hassager, O., Dynamics of Polymeric Liquids, Volume 2: Kinetic Theory, Wiley, New York (1987).

[10] Tanner, R. I., Engineering Rheology, Oxford Univ. Press, New York, (1990).

[11] Luckhurst, G. R., Stephens, R. A. and Phippen, R. W., Computer Simulation Studies of Anisotropic Systems. XIX. Mesophases Formed by the Gay-Berne Model Mesogen, Liq. Cryst., Vol. 8(4), 451-464 (1990) (doi:10.1080/ 02678299008047361).

[12] Lees, A. W. and Edwards, S. F., The Computer Study of Transport Processes under Extreme Conditions, J. Phys. C, Vol. 5(15), 1921-1929 (1972).

[13] Yamamoto, T. and Masaoka, N., Numerical Simulation of Star Polymers under Shear Flow Using a Coupling Method of Multi-Particle Collision Dynamics and Molecular Dynamics,
Rheol. Acta, Vol. 54(2), 139-147 (2015) (doi: 10.1007/s00397-014-0817-8).

[14] Yamamoto, T. and Masaoka, N., Numerical Simulation for Polymer Solutions Based on a Hybrid Computation of Multi-Particle Collision Dynamics and Coarse-Grained Molecular Dynamics, Proc. of PPS-29, AIP Conf. Proc., Vol. 1593, 578-581 (2014).

[15]Ji, S., Jiang, R., Winkler, R. G. and Gompper, G., Mesoscale Hydrodynamic Modeling of a Colloid in Shear-Thinning Viscoelastic Fluids under Shear Flow, J. Chem. Phys., Vol. 135(13), 134116 (2011) (doi: 10.1063/1.3646307).

[16] Vicsek, T. and Zafeiris, A., Collective Motion, Phys. Rep., Vol. 517(3-4), 71-140 (2012) (doi:10.1016/j.physrep.2012.03.004).

[17] Marchetti, M. C., Joanny, J. F., Ramaswamy, S., Liverpool, T. B., Prost, J., Rao, M. and Simha, R. A., Hydrodynamics of Soft Active Matter, Rev. Mod. Phys., Vol. 85(3), 1143-1189 (2013) (doi:10.1103/RevModPhys.85.1143).

[18] Ghorai, S. and Hill, N. A., Penetrative Phototactic Bioconvection, Phys. Fluids, Vol. 17(7), 074101 (2005) (doi:10.1063/1.1947807).

[19] Williams, C. R. and Bees, M. A., Photo-Gyrotactic Bioconvection, J. Fluid Mech., Vol. $678 \quad$ (2011), 41-86 (2011) (doi:10.1017/jfm.2011.100).

[20] Williams, C. R. and Bees, M. A., A Tale of Three Taxes: Photo-Gyro-Gravitactic Bioconvection, J. Exp. Biol., Vol. 214(14), 2398-2408 (2011) (doi:10.1242/jeb.051094).

[21] Yamamoto, T., Numerical Analysis of Dispersion Systems of Bio-Based Particles as Complex Fluids, RIMS Kôkyûroku, No. 1940, 61-67 (2015). 